\title{
Marine-derived fungi: diversity of enzymes and biotechnological applications
}

Rafaella C. Bonugli-Santos', Maria R. dos Santos Vasconcelos' ${ }^{2}$, Michel R. Z. Passarini', Gabriela A. L. Vieira ${ }^{3}$, Viviane C. P. Lopes ${ }^{3}$, Pedro H. Mainardi ${ }^{3}$, Juliana A. dos Santos ${ }^{3}$, Lidia de Azevedo Duarte ${ }^{3}$, Igor V. R. Otero ${ }^{3}$, Aline M. da Silva Yoshida ${ }^{3}$, Valker A. Feitosa ${ }^{4}$, Adalberto Pessoa $\mathrm{Jr}^{4}$ and Lara D. Sette ${ }^{2,3 *}$

OPEN ACCESS

Edited by:

Gavin J. Collins,

National University of Ireland, Ireland

Reviewed by:

Oded Yarden,

The Hebrew University of Jerusalem,

Israel

Ka-Lai Pang,

National Taiwan Ocean University,

Taiwan

${ }^{*}$ Correspondence:

Lara D. Sette,

Laboratório de Micologia Ambiental e Industrial, Departamento de

Bioquímica e Microbiologia, Instituto de Biociências, Universidade Estadual

Paulista Júlio de Mesquita Filho,

Avenida 24A, 1515 Bela Vista, Rio

Claro, SP 13506-900, Brazil

larasette@rc.unesp.br

Specialty section:

This article was submitted to Microbiotechnology, Ecotoxicology and Bioremediation, a section of the

journal Frontiers in Microbiology

Received: 27 November 2014 Accepted: 18 March 2015

Published: 10 April 2015

Citation:

Bonugli-Santos RC, dos Santos Vasconcelos MR, Passarini MRZ, Vieira GAL, Lopes VCP, Mainardi PH, dos Santos JA, de Azevedo Duarte L,

Otero IVR, da Silva Yoshida AM, Feitosa VA, Pessoa A Jr and Sette LD (2015) Marine-derived fungi: diversity of enzymes and biotechnological applications.

Front. Microbiol. 6:269. doi: 10.3389/fmicb.2015.00269
${ }^{1}$ Instituto Latino Americano de Ciências da Vida e da Natureza, Centro Interdisciplinar de Ciências da Vida, Universidade Federal da Integração Latino-Americana, Paraná, Brazil, ${ }^{2}$ Divisão de Recursos Microbianos, Centro Pluridisciplinar de Pesquisas Químicas, Biológicas e Agrícolas, Universidade Estadual de Campinas, Paulínia, Brazil, ${ }^{3}$ Laboratório de Micologia Ambiental e Industrial, Departamento de Bioquímica e Microbiologia, Instituto de Biociências, Universidade Estadual Paulista Júlio de Mesquita Filho, Rio Claro, Brazil, ${ }^{4}$ Departamento de Tecnologia Bioquímico-Farmacêutica, Faculdade de Ciências Farmacêuticas, Universidade de São Paulo, São Paulo, Brazil

The ocean is considered to be a great reservoir of biodiversity. Microbial communities in marine environments are ecologically relevant as intermediaries of energy, and play an important role in nutrient regeneration cycles as decomposers of dead and decaying organic matter. In this sense, marine-derived fungi can be considered as a source of enzymes of industrial and/or environmental interest. Fungal strains isolated from different substrates, such as invertebrates, decaying wood, seawater, sediments, and mangrove detritus, have been reported to be producers of hydrolytic and/or oxidative enzymes, with alginate lyase, amylase, cellulase, chitinase, glucosidase, inulinase, keratinase, ligninase, lipase, nuclease, phytase, protease, and xylanase being among the enzymes produced by fungi of marine origin. These enzymes present temperature and $\mathrm{pH}$ optima ranging from 35 to $70^{\circ} \mathrm{C}$, and 3.0 to 11.0 , respectively. High-level production in bioreactors is mainly performed using submerged-state fermentation. Certain marine-derived fungal strains present enzymes with alkaline and cold-activity characteristics, and salinity is considered an important condition in screening and production processes. The adaptability of marinederived fungi to oceanic conditions can be considered an attractive point in the field of fungal marine biotechnology. In this review, we focus on the advances in discovering enzymes from marine-derived fungi and their biotechnological relevance.

Keywords: marine-derived fungi, enzymes, marine mycology, culture-dependent methods, culture-independent methods, environmental pollutants, industrial microbiology

\section{Introduction}

Marine microbial communities (bacteria, fungi, algae, plankton, and viruses) are considered important ecological components in marine environments due to their performance in biogeochemical processes (Sowell et al., 2008). Marine fungi have been classified as obligate or facultative: obligate marine fungi are those that grow and sporulate exclusively in a marine or estuarine habitat, whereas facultative marine fungi are those from freshwater or 
terrestrial origin that are able to grow (and possibly sporulate) in marine environments (Kohlmeyer and Volkmann-Kohlmeyer, 2003; Li and Wang, 2009). As a more general classification of these organisms, the term "marine-derived fungi" is often used because most of the fungi isolated from marine samples are not demonstrably classified as obligate or facultative marine microorganisms (Osterhage, 2001).

Many factors can influence the activity, abundance and distribution of fungi in the marine environment. The occurrence of marine fungi has been reported in different substrates (e.g., sponges, algae, wood, tunicates, sediments, mollusks, corals, plants, fish), and the ecology and phylogeny of this group are summarized in Jones (2000), Jones et al. (2009, 2011), Jones and Pang (2012) and Richards et al. (2012). A great diversity of fungi has been recovered from along coastlines, such as mangrove, sand, beach, river, and estuarine habitats, suggesting that environmental influences such as floods and winds carry terrestrial fungi toward marine environments. Thus, marine-derived fungi often routinely exhibit morphological characteristics similar to their terrestrial counterparts (Mejanelle et al., 2000; MorrisonGardiner, 2002).

A wide range of activities has been identified from marine environment, including antibacterial, antidiabetic, antifungal, anti-inflammatory, antiprotozoal, antituberculosis, antiviral, antitumor, and cytotoxic activities, many of which can be attributed to specific enzymes (Mayer et al., 2013). Although some reports related to enzyme production by marine-derived fungi appeared in the 1980s, studies on this subject started to be published more frequently after 1999-2000 (Velmurugan and Lee, 2012). Salinity, high pressure, low temperature, oligotrophic conditions, $\mathrm{pH}$ extremes, widely ranging mineral content in seawater, and special lighting conditions contribute to the differences between the enzymes generated by marine microorganisms and homologous enzymes from terrestrial microorganisms (Booth and Kenkel, 1986; Jones, 2000; Gomes et al., 2008; Madhu et al., 2009; Pang et al., 2011; Intriago, 2012; Passarini et al., 2013; Rämä et al., 2014).

Due to their immense genetic and biochemical diversity, marine microorganisms are viewed as a new promising source of enzymes with potential technological applications (Debashish et al., 2005; Zhang and Kim, 2012). The market for marine fungal enzymes is divided into four segments: (i) technical enzymes, mainly intended for cleaning, textile, leather, biofuel, pulp, and paper industries; (ii) enzymes for food and beverages; (iii) enzymes for animal feed; (iv) enzymes related to environmental applications; and (v) enzymes related to pharmaceutical and cosmetic applications.

The advances in discovering enzymes from marine-derived fungi and their biotechnological relevance are discussed below.

\section{Production of Enzymes by Marine-Derived Fungi}

\section{Accessing Marine-Derived Fungal Strains}

Culture-dependent approaches have served as the main techniques utilized to obtain fungal enzymes for biotechnological applications. However, it is expected that in the near future, molecular applications, such as those based on using recombinant DNA, may be routinely applied for marine enzyme expression directly from metagenomic libraries. Such techniques could allow access to the enzymes produced by microbial communities that are not culturable in the laboratory and allow the discovery of new compounds that can be used in biotechnology, as discussed by Voget et al. (2003) and Singh (2010).

The fungal isolation process begins with substrate sampling. Kjer et al. (2010) reported common methodologies for sample collection and discussed special conditions for the storage of animal and seaweed tissue, and mangrove leaf samples. Surface sterilization of the sample may be performed by repeated washing with sterilized seawater or artificial seawater (ASW). In the study of Menezes et al. (2010), marine invertebrate samples were first sterilized with mercury chloride (in ethanol) and then washed twice with sterilized seawater. In contrast, Passarini et al. (2013) only washed the samples with sterilized seawater, showing an improvement in the rate of fungal recovery. The results from these studies suggest that mercury chloride can reach internal tissues and kill some microbial cells. After surface sterilization, samples can be directly inoculated on agar culture media by plating pieces $\left(1 \mathrm{~cm}^{3}\right)$ of the substrate or using the pour-plate technique after substrate trituration and serial dilution.

Different laboratory conditions are applied for the recovery of fungal strains from marine substrates. The greatest diversity can be recovered using poor and rich media, and different temperature, $\mathrm{pH}$, and oxygen conditions. Salinity is an important condition and can be achieved using sterilized seawater or ASW. The culture media typically found in the literature for marine-derived fungal growth are as follows: Glucose Agar, Sabouraud Agar, Boyd, and Kohlmeyer Agar (B\&K; Kohlmeyer and Kohlmeyer, 1979), Peptone and Yeast Extract Dextrose Agar, Marine Agar, Potato Dextrose Agar, Malt Agar, Cornmeal Agar, and Oat Agar.

Kjer et al. (2010) described a detailed protocol for the isolation, purification and characterization of endophytic marinederived fungi, and Sponga et al. (1999) discussed the isolation of fungi from marine sediments and sponges. Hallmann et al. (2006), Abdel-Monem et al. (2013), and Sette and Bonugli-Santos (2013) also mention the use of specific nutrients or compounds with particular toxicity levels for the selection of slow-growing fungi. For yeast isolation, alternative methods have been reported by Brauers et al. (2000) and Schulz et al. (2008), and enrichment methods were applied by Dhevagi and Poorani (2006) and Mohan et al. (2013) for the isolation of marine actinobacteria. However, to our knowledge, there are no reports in the available literature related to enrichment strategies for fungal isolation from marine substrates. Additional information related to the isolation of marine-derived fungi can be found in Vrijmoed (2000) and Nakagiri (2012).

After isolation, fungal strains are purified and preserved, though there is no universal method for microbial preservation because the response to the different methods varies among taxonomic groups and even among strains of the same species. The World Federation for Culture Collections Guidelines (WFCC, 2010), Guidance for the Operation of Biological Research 
Centers (OECD, 2007), and Guide for the Operation of Cultures Collections from the Brazilian Society of Microbiology (Sette et al., 2007) list a number of guidelines related to the maintenance and preservation of microbiological material. Some factors must be considered when choosing the most appropriate preservation method: (i) the storage period; (ii) the continued viability of the lineage properties; and (iii) the importance of the collection with respect to biodiversity and biotechnological potential. The use of at least two preservation methods is emphasized in all the guidelines cited above; these guidelines also mention issues related to biosecurity and biosafety.

The recommended preservation methods and distribution forms for filamentous fungi and yeasts are summarized in the study reported by Sette et al. (2013) and are listed in Table $\mathbf{1}$.

Several studies have explored metabolites from marinederived fungi using a culture-dependent approach (Bugni and Ireland, 2004). In this sense, it is expected that a great number of isolates may be preserved in culture collections from different institutions all over the world, representing a potential source of microbial genetic resources for biotechnological applications. According to Sette et al. (2013), research programs should be put in place as part of culture collection activities, as recommended by WFCC (2010) Guidelines, because it not only helps to attract high-quality staff but can also make an important contribution to the knowledge of the groups of organisms maintained in such collections. In addition, these programs ensure that staff keep abreast of current developments and are aware of the needs of the user community.

It is important to mention that, regardless of the manner in which the microbial genetic resources were obtained (culturedependent or culture-independent approaches), the access (use) of microbial biodiversity must follow national and international rules, including those established by the Convention on Biological Diversity (CBD, 2011), especially the Nagoya Protocol on Access and Benefit Sharing - ABS.

\section{Screening and Culture Conditions}

There is no single method for screening new enzymes, but preference should be given to the use of low-cost, rapid, and sensitive techniques. When a large number of microorganisms is to be evaluated, high throughput screening (HTS) or medium throughput screening (MTS) methods should be considered in the prospecting stage (Sette et al., 2013). In a somewhat arbitrary definition, 'medium throughput' indicates several 100 determinations per day, whereas 'high throughput' is currently considered to imply the evaluation of 1,000-10,000 samples per day (Reetz, 2006).

TABLE 1 | Recommended preservation methods for filamentous fungi and yeasts (Sette et al., 2013).

\begin{tabular}{ll}
\hline Sporulating strains & Non-sporulating strains \\
\hline Cryopreservation below $-140^{\circ} \mathrm{C}$ (is preferred) & Under oil or water \\
Cryopreservation below $-80^{\circ} \mathrm{C}$ (is accepted) & Freeze-drying \\
Freeze-drying/Liquid-drying & Cryopreservation
\end{tabular}

Screening can often begin in the isolation step with the addition of specific nutrient sources (e.g., polyaromatic hydrocarbons - PAHs, pesticides, antimicrobials, inductors) in the culture medium to preferentially select the microorganism able to produce the target enzyme ( $\mathrm{Da}$ Silva et al., 2004). Colorimetric methods in Petri dishes have been widely used for the selection of microbial enzymes. In these methods, the target enzyme converts a colorless substrate into a colored one or changes the medium color, as used for the screening of asparaginase and glutaminase (Thenmozhi et al., 2011; Patil et al., 2012; Dhale and MohanKumari, 2014), ligninases (Verma et al., 2010; Chen et al., 2011), lipases (Duarte et al., 2013), xylanases, and cellulases (Azad et al., 2013). Analysis of halos, formed by substrate degradation around the colony, may be applied, such as for protease screening (Zhang and Kim, 2010).

During the screening and production of enzymes from marine samples, the presence of salt can be crucial as it is presumed that marine-derived fungal metabolism is adapted to ocean salinity (D'Souza et al., 2006; Chen et al., 2011). Chen et al. (2011) and Bonugli-Santos et al. (2012) achieved better results in lignindegrading enzyme selection when saline conditions (ASW) were applied. Additionally, Arfi et al. (2013) reported the secretion of salt-adapted lignocellulolytic enzymes from the mangrove fungus Pestalotiopsis sp. Table 2 lists a selection of enzymes produced by marine-derived fungi, growth conditions, and their characteristics; for all enzymes cited, salinity was considered in the culture conditions.

The fungal production of enzymes depends on its physiology, as well as on culture medium composition (Baldrian and Gabriel, 2003). Carbon and nitrogen sources play an important role in enzyme production; their effects have been investigated in numerous fungi from terrestrial environments and are also relevant for marine-derived fungi. Complex substrates, such as starch, casein, pectin, malt extract, wheat bran, olive oil, xylan, and sugarcane bagasse, are used for the production of enzymes by marine-derived fungi (Table 2). The enzymes listed in Table 2 were produced by fungal strains recovered from different substrates, including marine invertebrates (sponges and cnidarian), sediments, algae, decaying wood, and leaf detritus. The optimum temperature and $\mathrm{pH}$ of these enzymes ranges from 37 to $70^{\circ} \mathrm{C}$ and from 3 to 9 , respectively.

Additional information on the screening and production of enzymes by marine fungi can be found in Hyde and Pointing (2000), and Velmurugan and Lee (2012).

Because culture conditions clearly influence the production of enzymes, the best way to improve their production is the use of experimental design and statistical analysis. This methodology has been successfully applied to terrestrial fungi (Levin et al., 2008) and provides an efficient approach to determining the best culture conditions for maximizing enzyme production, which in turn can lead to process optimization. Implementing the statistical methodology central composite design, Bonugli-Santos et al. (2010a) concluded that manganese peroxidase production by marine-derived Mucor racemosus CBMAI 847 is most likely related to salt concentration. D'Souza-Ticlo et al. (2009) demonstrated the relevance of the use of response surface methodology in the evaluation of the effects and interactions of medium 


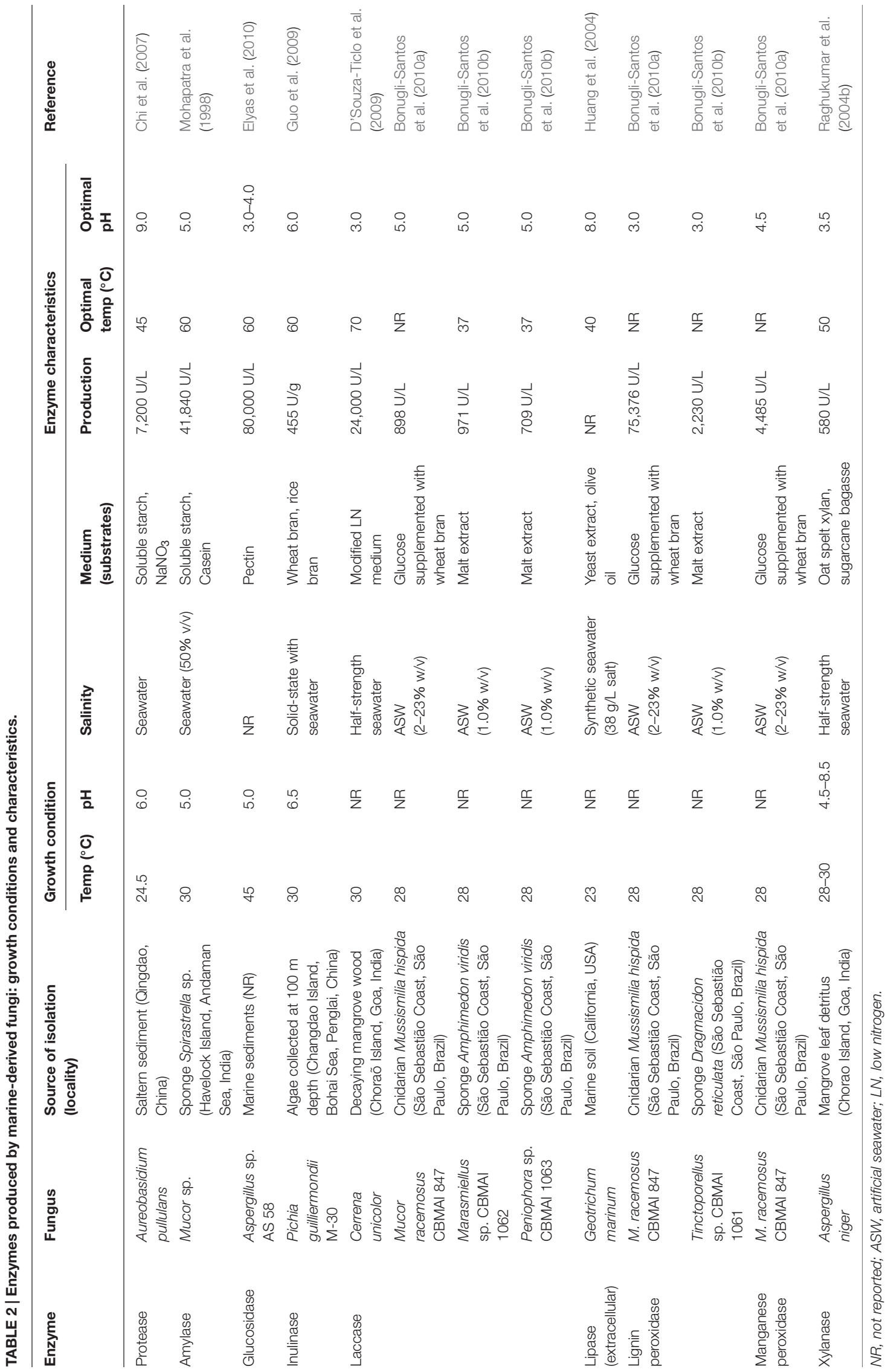


components on laccase production by a marine-derived fungus. In this study, low concentrations of $\mathrm{NH}_{4} \mathrm{Cl}$ and high concentrations of glucose were found to favor the production of biomass.

\section{Bioprocess}

After the optimum culture conditions on a small scale are defined (flasks with shaking), studies related to enzyme production on a larger scale (bioreactors) and scaling-up, which is defined by Bliem and Katinger (1988) as the predictable (engineered) increase in production capacity, must be performed. Substrate consumption, product formation, and cellular biomass are important factors, which should be considered, and quantified, for appropriate scale-up studies. Marine-derived fungal strains adapted to liquid medium may attenuate some of the issues found with terrestrial strains, such as biomass measurement. Additionally, water-adapted strains may show increased enzyme production (Verbist et al., 2000; Masuma et al., 2001).

The large-scale production (e.g., in bioreactors) of glucoamylase, superoxide dismutase, lignin peroxidase, chitinase, protease, and glutaminase by marine strains is reported in the literature (Sarkar et al., 2010). These enzymes are produced in bioreactors largely through submerged-state fermentation, and the conditions related to bioreactor production are listed in Table 3.

Trincone (2011) described an overview of the bioprocess strategies adopted for the cultivation of marine-derived organisms for enzyme production, including protease, chitinase, agarase, and peroxidase. For further discussion about marine enzyme production and novel prospects, see Kristensen et al. (2008) and Trincone (2010).

For many industrial applications, enzymes need to be concentrated, separated, and/or purified from the medium, and the purification strategies employed should be inexpensive, have a high yield and selectivity, be amenable to large-scale operations and should have the potential for continuous product recovery (Gupta et al., 2004; Singh and Mukhopadhyay, 2012). In some cases, purification methodologies need to be adapted to maintain the integrity of the enzymes because catalytic activity is dependent upon conformational structure. Several strategies can be applied to obtain purified enzymes. However, specific studies for establishing strategies of marine enzyme purification are scarce. Some reports of marine-derived fungal enzyme isolation and purification are presented in Table 4. The degree of purification varies significantly as a function of the number and order of steps, and the purification process in most cases is based on sequential steps, with low and high resolution. In general, lowspecificity methods are employed, such as concentration followed by chromatography. Purification processes applied to enzymes from marine fungal strains (Table 4) can reach a recovery yield of $66 \%$ and a purification factor up to 647 -fold. In most cases, increasing the number of steps leads to greater enrichment, albeit a severe decrease in yield is observed.

Once the purified enzyme is successfully obtained, relevant information can be achieved through physicochemical and biochemical characterization. These characteristics are essential for guiding an effective choice of large-scale purification strategy and realizing the application potential of the enzyme. It is noteworthy that no industrial processes for enzyme purification of marine

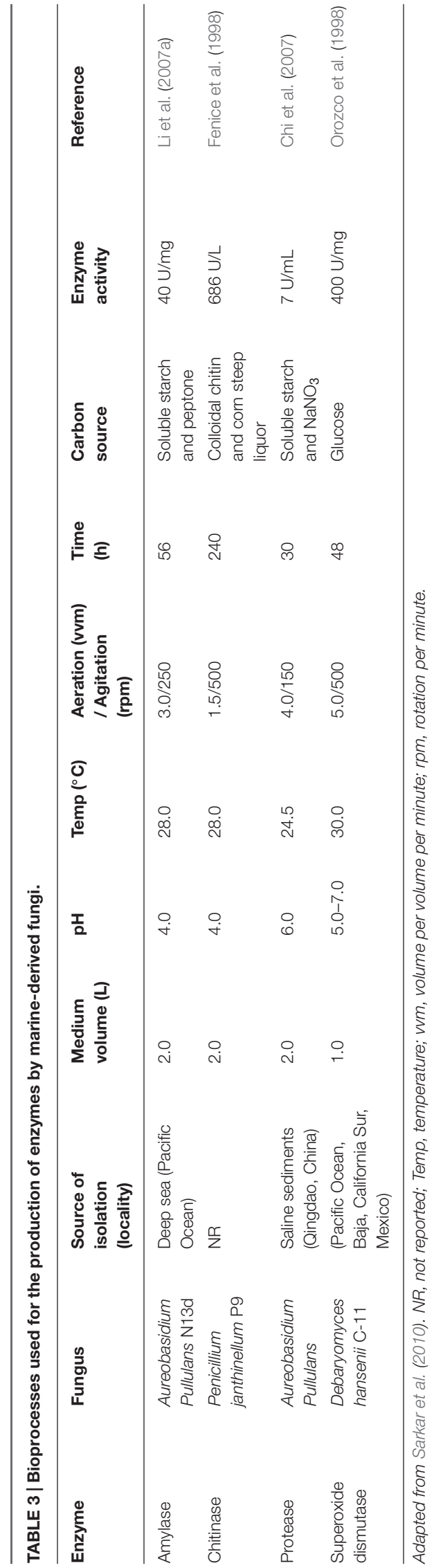




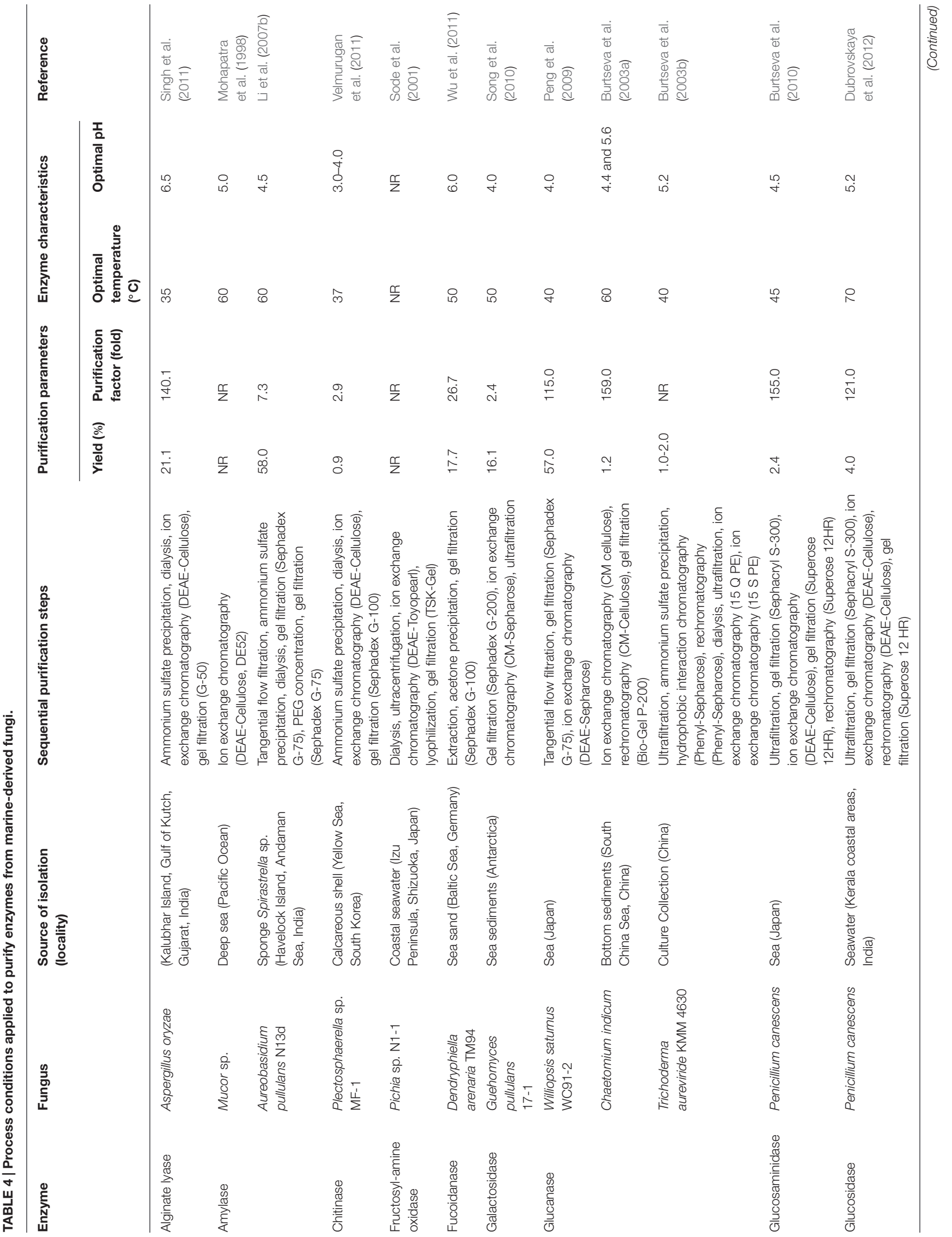




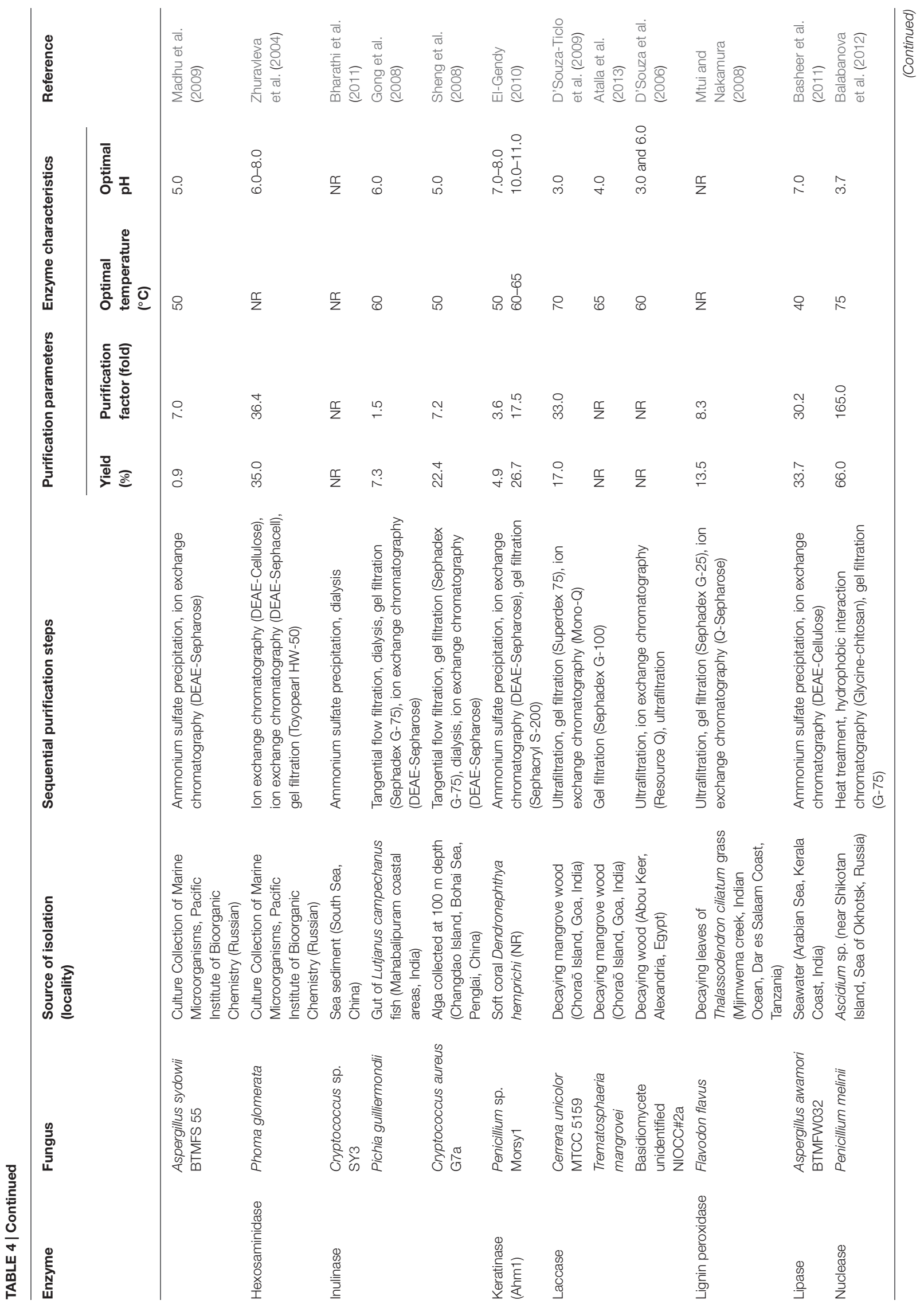




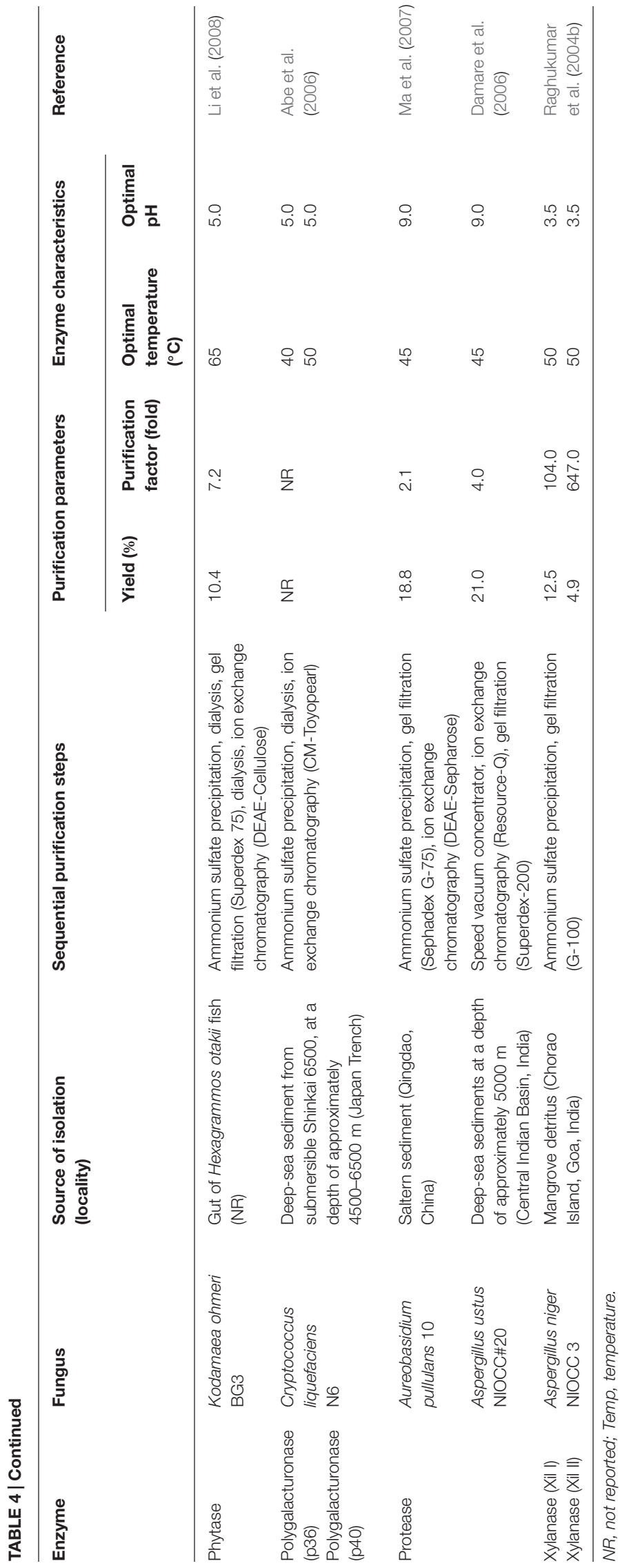

origin were found in the available literature. Data from the studies cited in Table 4 show that the temperature and $\mathrm{pH}$ optima of the purified enzymes produced by marine-derived fungal strains ranged from 35 to $75^{\circ} \mathrm{C}$ and 3.0 to 11.0 , respectively.

The vast majority of the enzymes cited in Tables 3 and $\mathbf{4}$ were obtained from ascomycetes fungi, with a small percentage produced by representatives of basidiomycetes. The predominance of ascomycetes in aquatic habitats has been discussed in the literature, with the major hypothesis for explaining this predominance being the presence of spores with adaptation (appendages) to the aquatic ecosystem (Hyde and Jones, 1989; Prasannarai and Sridhar, 2001; Vijaykrishna et al., 2006). This group represents fungi that are readily cultivable and can be easily recovered when culture-dependent techniques are applied (Baker et al., 2009). Conversely, basidiomycetes fungi are rarely isolated from marine samples (Menezes et al., 2010).

Different species from the genera Aspergillus and Penicillium are cited as marine-derived producers of enzymes. These fungi are salt-tolerant and have been reported in the literature as invertebrate-inhabiting fungi (Holler et al., 2000; Da Silva et al., 2008; Baker et al., 2009; Menezes et al., 2010). The Aspergillus sp. and Penicillium sp. cited in Tables $\mathbf{3}$ and $\mathbf{4}$ were recovered from marine invertebrates, seawater, deep sediments, and mangrove detritus.

\section{Biotechnological Potential}

Regarding the ecological role of fungi of marine origin, studies have demonstrated that their main activities are indeed associated with the decomposition of organic matter. Within this context, a great diversity of hydrolytic and oxidative enzymes, which can be used in biotechnological processes, have been reported for different species of marine fungi (Tables 2-4).

According to Velmurugan and Lee (2012), marine-derived fungi are able to produce enzymes with novel physiological characteristics, such as high salt tolerance, thermostability, barophilicity, and cold-activity. However, few studies to date have shown that enzymes from marine fungal strains are different from those produced by their terrestrial counterparts (Chi et al., 2009). Alkaline xylanases and thermostable metal-tolerant laccases are produced by marine-derived strains of Aspergillus niger and Cerrena unicolor (Raghukumar et al., 2004b; D’Souza-Ticlo et al., 2009). Low-temperature active endoglucanases were obtained by several fungal strains from the marine sponge Haliclona simulans in Ireland (Baker et al., 2010), and cold-active xylanase was produced by a marine-derived Cladosporium sp. (Del-Cid et al., 2014) and by a recombinant marine fungal strain (a psychrotrophic fungus from the Yellow Sea; Hou et al., 2006). Chitinases active at low temperatures $\left(5\right.$ and $\left.10^{\circ} \mathrm{C}\right)$ were also reported by Fenice et al. (1998) and Velmurugan et al. (2011). Lipases, proteases and cellulases were reported to be produced on solid media at $15^{\circ} \mathrm{C}$ by Antarctic marine yeast strains isolated from marine samples (e.g., different marine invertebrates and sediments; Duarte et al., 2013).

Cold-active microbial enzymes have attracted increasing attention in recent years (Wang et al., 2012). In addition to 
the properties related to their structural characteristics, one of the main advantages related to the use of these enzymes is the decrease energy expenditure and processing costs associated with industrial heating steps (Duarte et al., 2013). Salt-tolerant fungi and their salt-tolerant enzymes (mainly lignin-degrading enzymes) have been used for bioremediation of environmental pollutants (Passarini et al., 2011), as described in Section "Environmental Applications." The discovery of barotolerant enzymes is still in the initial phase (Velmurugan and Lee, 2012).

The potential ability of marine-derived fungi to grow on relatively rather simple and inexpensive substrates, and produce enzymes with different physiological characteristics can place them at the forefront of contemporary commercial applications.

\section{Environmental Applications}

\section{Decolorization of Synthetic Dyes and Textile Effluents}

Residual dyes from different sources introduce organic pollutants into natural water resources or wastewater treatment systems (Zaharia and Suteu, 2012). These dyes belong to classes of compounds with azo, anthraquinone, triphenylmethane, and heterocyclic polymeric structures. According to Diwaniyan et al. (2010), azo dyes are the largest and most versatile class of dyes and account for more than half of the annually produced synthetic dyes.

In aquatic ecosystems, dyes can interfere with photosynthesis and the diffusion of gasses and are of human health concern (Baughman and Weber, 1994; Ciullini et al., 2008). Furthermore, these compounds are often recalcitrant, and their removal from wastewater is difficult and expensive (Hao et al., 2000). In this regard, considerable effort has focused on developing efficient and cost-effective technologies for treating wastewater dyes, including bioremediation, a process in which biological agents are used to degrade environmental pollutants. Bioremediation is based on the exploration of microbial populations that can modify or decompose certain pollutants (Peixoto et al., 2008). Microorganisms used in remediation can be considered as an attractive biotechnological alternative for achieving possible mineralization of the pollutant and its transformation into less toxic products with greater solubility in water, which can then be degraded by the action of other microorganisms (Cerniglia, 1997; Cerniglia and Sutherland, 2001).

Several fungi are known to be capable of degrading persistent pollutants (Haritash and Kaushik, 2009), including textile dyes. Because a large number of textile processes can generate effluents having saline and alkaline conditions, fungi from marine environments demonstrate an important biological advantage for effluent decolorization/degradation because these fungi are adapted to high salt and $\mathrm{pH}$. The dye decolorization mechanism by fungal cells includes oxidative reactions, which can generate non-toxic derivatives (Ciullini et al., 2008). Among the extracellular enzymes produced by filamentous fungi, the ligninolytic system is of great relevance in environmental remediation (Arun et al., 2008).

Raghukumar et al. (1996, 2004a, 2008) and D'Souza et al. (2006) showed significant decolorization of textile effluents and synthetic dyes (e.g., Congo red, Brilliant green, and RBBR) by marine-derived fungi. Other research groups have been focused on the use of marine-derived filamentous fungi for synthetic dye decolorization (Junghanns et al., 2008; Bonugli-Santos et al., 2012; Chen et al., 2014). In the study conducted by Chen et al. (2014), a whole-cell immobilization system (using marinederived fungi Pestalotiopsis sp. J63 and Penicillium janthinellum P1) showed the ability to decolorize Azure B dye.

Nutrients and physical parameters have a significant effect on dye decolorization (Singh et al., 2013), and the mechanism involving laccase can differ depending upon the dye structure (D’Souza et al., 2006). According to Verma et al. (2010), marine-derived fungi were able to decolorize two textile effluents: TEA (containing an azo dye with a $\mathrm{pH}$ of 8.9 ) and TEB (containing a mixture of eight reactive dyes with a $\mathrm{pH}$ of 2.5). The ascomycetes and basidiomycetes studied presented 30 to $60 \%$ TEA decolorization and 33 to $80 \%$ TEB decolorization, respectively, under saline conditions. Additional analyses of toxicity (measured by LC50 values against Artemia larvae) and a mass spectrometric scan of effluents after fungal treatment revealed degradation of most of the effluent components. The better capacity of marine-derived basidiomycetes to decolorize and degrade textile dyes corroborates the results of many studies cited in literature using terrestrial basidiomycetes fungi. Indeed, basidiomycetes are considered the best producers of ligninolytic enzymes, mainly those classified as white-rot fungi.

Sponge-derived basidiomycetes showed the ability to decolorize textile dyes in solid medium under both saline and nonsaline conditions (Bonugli-Santos et al., 2012). Additionally, complete RBBR decolorization was reached in liquid medium, with the best decolorization obtained using Tinctoporellus sp. CBMAI 1061 after 3 days of incubation at two concentrations of RBBR (500 and 1,000 mg/L). RBBR was also reported to be degraded by filamentous fungi isolated from scleractinian coral and zoanthids collected along the north coast of São Paulo State, Brazil. In another study, Penicillium citrinum CBMAI 853 was the most efficient fungus, decolorizing RBBR (100\%) after 12 days, followed by A. sulphureus CBMAI 849 (95\%), Cladosporium cladosporioides CBMAI 857 (93\%) and Trichoderma sp. CBMAI 852 (89\%; Da Silva et al., 2008).

According to Raghukumar et al. (2004a), marine-derived fungi are often more effective than terrestrial fungi in the treatment of various colored effluents because they are better adapted to perform under extreme conditions (high salinity).

\section{Degradation of Polycyclic Aromatic Hydrocarbons (PAHs)}

Polycyclic aromatic hydrocarbons (PAHs) are widely distributed in the environment and may persist for extended periods of time (Shuttleworth and Cerniglia, 1995). PHA molecules are composed of two or more fused benzene rings and are formed during the combustion of organic molecules and its subsequent recombination (Haritash and Kaushik, 2009). Forests, oil seeps, volcanic eruptions and exudates from trees constitute some natural sources of PAHs. Anthropogenic 
sources of PAH include fossil fuel burning, coal tar, wood, garbage, refuse, waste lubricating oil, and oil filters, municipal solid waste incineration and petroleum spills and discharge (Kaushik and Haritash, 2006). Certain PHAs are considered toxic, mutagenic, and carcinogenic (Peakall et al., 1982).

The basis for the various known mechanisms of the aerobic metabolism of PAHs involves the oxidation of the aromatic ring (Bamforth and Singleton, 2005). The ligninolytic system and the monooxygenase system of cytochrome P-450 may be involved in PAH degradation by filamentous fungi (Haritash and Kaushik, 2009).

Passarini et al. (2011) reported that the fungus A. sclerotiorum CBMAI 849 showed $99.7 \%$ pyrene (2 $\mathrm{mg}$ in $30 \mathrm{~mL}$ ) and $76.6 \%$ of benzo[a]pyrene $(1 \mathrm{mg}$ in $30 \mathrm{~mL}$ ) degradation after 8 and 16 days, respectively. Benzo[a]pyrene depletion (>50.0\%) was also achieved by Mucor racemosus CBMAI 847. HPLC-DAD-MS data showed that A. sclerotiorum CBMAI 849 and M. racemosus CBMAI 847 are able to metabolize pyrene to pyrenylsulfate and benzo[a]pyrene to benzo[a]pyrenylsulfate, suggesting that the mechanism of hydroxylation is mediated by a cytochrome P-450 monooxygenase, followed by conjugation with sulfate ions. In the study performed by Wu et al. (2009), Aspergillus sp. BAP14 isolated from marine sediment (the China coast) showed the ability to degrade benzo[a]pyrene: the fungus was able to remove approximately $30 \%$ and $60 \% \mathrm{BaP}(0.010 \mathrm{mg} / \mathrm{mL})$ after 3 and 12 days, respectively. In another study, two nonidentified marine-derived fungi (NIOCC\#312 and NIOCC\#2a) were able to remove phenanthrene from a culture medium by adsorption on the fungal mycelium (Raghukumar et al., 2006).

Considering that the use of marine-derived fungi for the bioremediation of polluted saline environments is facilitated by their tolerance to saline conditions, these microorganisms are important microbial resources for biotechnological application in the bioremediation of PAH-polluted environments, such as ocean and marine sediments.

\section{Industrial Applications}

Different enzymes produced by marine-derived fungi have been reported in the literature and are related to the industrial production of: (i) lipases, for the development of cosmetics and as components of medicine (digestive enzymes) or clinical reagents (Zhang and Kim, 2010; Murray et al., 2013); (ii) proteases, for the production of digestive and anti-inflammatory drugs (Zhang and Kim, 2010); (iii) ligninases, with biotechnological applications in many sectors, including such industries as the chemical, fuel, food, agricultural, paper, textile, and cosmetic (Raghukumar et al., 1994; Sette and BonugliSantos, 2013); and (iv) others compounds (e.g., L-glutaminase, tannase, and alginase), with potential application in the pharmaceutical and food/beverage sectors (Velmurugan and Lee, 2012).

The proportion of enzymes utilized for food and beverages is constantly growing, with an above-average growth forecast for the next years due to the demand for new applications in the dairy and baking sectors, among others. Studies have highlighted the advances in food technology and have noted marine microorganism capabilities in the production of active compounds, including proteins, and enzymes (Basheer et al., 2011; Dewapriya and Kim, 2014).

Ligninolytic enzymes present important biotechnological properties, since they might be able to degrade a wide variety of substrates via free radical-mediated oxidizing reactions. These enzymes can also be considered a great resource in the biofuel field, due to the possible resistance and activity in the presence of solvents and different $\mathrm{pH}$ conditions. Although there are no reports in the available literature related to the use of marine-derived fungi or their enzymes for ethanol production (second generation), Raghukumar et al. (2004b) showed efficient lignin mineralization by the basidiomycete fungus NIOCC\#312 isolated from decaying sea grass. Additionally, Intriago (2012) reported the prospect of utilizing marine microorganisms in cellulosic ethanol production. It is important to highlight that fungi classified as basidiomycetes are the best producers of ligninolytic enzymes; therefore, this class of fungi should be considered as the target in studies related to industrial and environmental applications (Chung et al., 2000), including the biological treatment of lignocellulosic substrate for biofuel production.

Despite the relevance of marine-derived fungal enzymes, available data concerning requests or deposits of patents associated with biotechnology using these fungi are lacking. The patents related to marine biotechnology filed in the World Intellectual Property Organization (WIPO) database are mostly associated with bacteria and cyanobacteria.

For data collection, a search was performed in four databases: European Patents Office (EPO), Espacenet-LatPat (Latin, America, and Spain), Industrial Property National Institute (INPI; Brazil), and Bioprospecting Information Resource (United Nations University, Japan). Of these, only EPO afforded results when using the keywords "marine fungi" and "enzyme from marine fungi." Fourteen filed patents were found, but only eleven are related to biotechnology; none of the registered patents is related to enzyme production.

Another search related to patents based on marine organisms was performed in Bioprospecting Information Resource (database) using a general search (it was performed only in this database due to its smaller size). A total of 105 patents (or requests) were found. The results showed only one German patent related to an unidentified filamentous fungus associated with the marine sponge Xestospongia exigua, which is used for the synthesis of biomolecules with pharmaceutical properties. Additionally, a Japanese patent was found related to pectinase production by the yeast Cryptococcus sp. The search revealed a low number of marine-derived fungal patents, with $46.6 \%$ of the patents (or requests) being related to other marine microorganisms, such as bacteria and archaea. In a previous survey conducted by Teixeira et al. (2010) using the Brazilian database (INPI), 39 patents were found, with $84 \%$ referring to algae, $9 \%$ to animals, $3 \%$ to various microorganisms and $3 \%$ to other organisms (non-specified).

Among the marine organisms with biotechnological potential, there are comparatively few requests and patent records for 


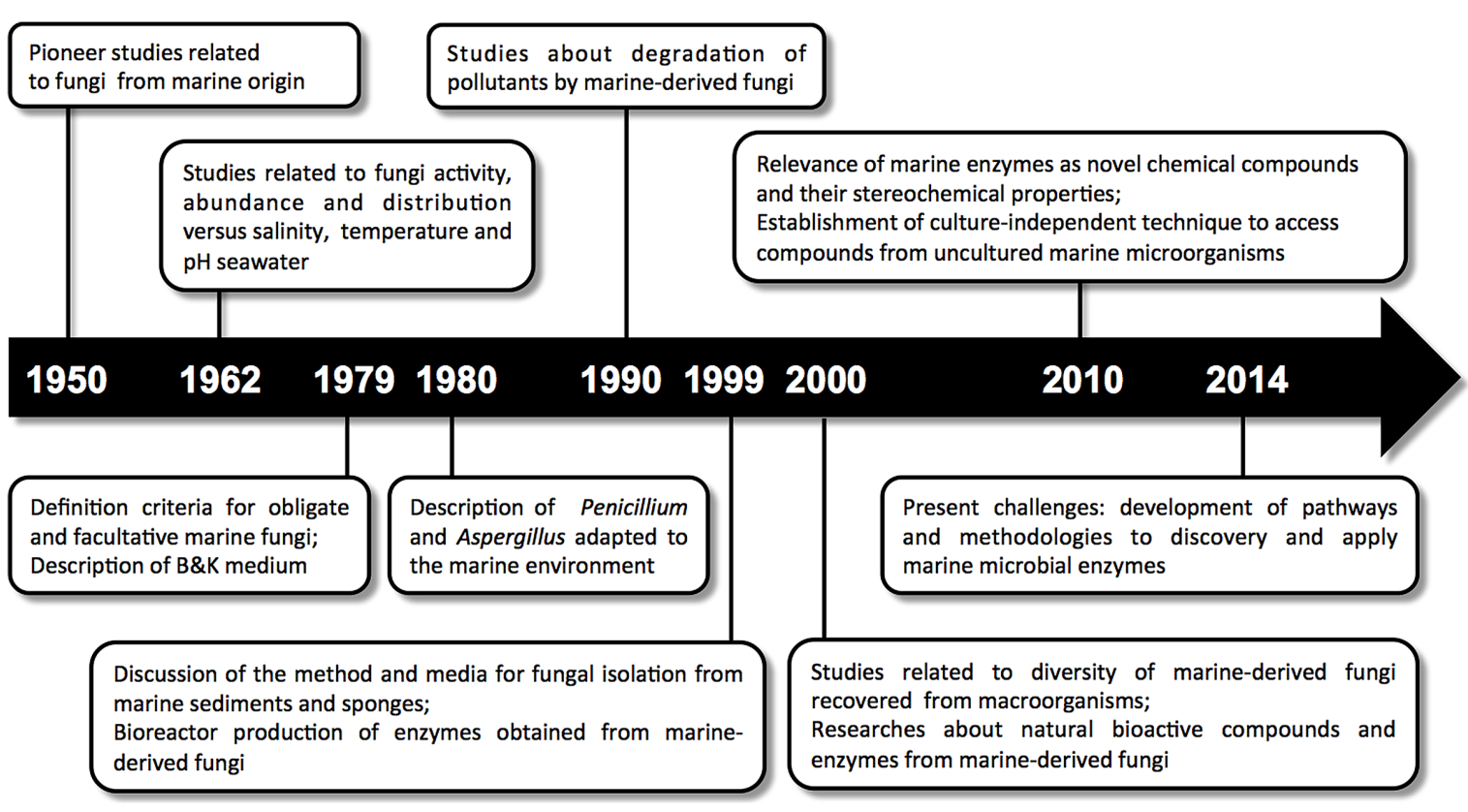

FIGURE 1 | Timeline of marine mycology: a brief account of the relevant scientific events related to marine-derived fungi and their enzymes.

fungi. However, considering the timeline related to the field of marine mycology (Figure 1), including the current advances in this area, a significant increase in patent applications should be observed in a near future. In 2014, our research group deposited a patent request at INPI (INPI deposit number BR 102014 0085025 ) related to the process of laccase enzyme production by the marine-derived basidiomycetes Peniophora sp. CBMAI 1063 (laccase enzyme and its use). This enzyme is highly produced only under saline conditions, clearly showing the influence of the marine environment on the production of this enzyme.

\section{Conclusion and Future Perspectives}

Studies related to the prospecting of marine-derived fungal enzymes could result in the discovery of new enzymes that are different from their terrestrial counterparts and also increase our understanding about the diversity and ecology of this microbial group. Taking into account that marine ecosystems are considered a poorly explored environment, and in light of the ongoing studies related to marine-fungal diversity based on culturedependent and independent approaches, it is reasonable to expect that new fungal taxa recovered from marine habitats will be reported in the short term.

Marine conditions (e.g., salinity, pressure, temperature, and light) contribute to the significant differences between the enzymes produced by marine microorganisms and homologous enzymes from their terrestrial counterparts. However, studies related to the effective difference of these enzymes have not been thoroughly evaluated. Such studies will support applications, and augment our understanding of the ecology, of marinederived fungi. Molecular characterization, crystallography, and enzyme modulation combined with classical enzymology assessment could assist in addressing questions related to catalyzes and functions. Additionally, studies related to gene transfer should be encouraged to accelerate the development of economically viable biotechnologies associated with the application of marine-derived fungi in the industrial and environmental sectors.

The results presented in this review highlight the potential of marine-derived fungal enzymes for biotechnology. To improve access to marine microorganisms and the use of their enzymes, national and international programs should be established, including the provision of facilities for marine microbial sampling (especially in extreme environments, such as the deep sea); cultivation; prospecting; preservation; and maintenance of culture collections.

\section{Acknowledgments}

The authors wish to thank São Paulo Research Foundation (FAPESP), National Council for Scientific and Technological Development $(\mathrm{CNPq})$, and Coordination for the Improvement of Higher Education Personnel (CAPES) for financial support such as scholarships to RS (FAPESP 2009/18399-1), MV (FAPESP 2011/18769-3), MP (FAPESP 2008/06720-7), GV (FAPESP 2012/12622-3), VL (CAPES), PM (FAPESP 2013/12505-0), JS (CAPES), LD (FAPESP 2014/12430-2), IO (CNPq 159488/2014), AY (FAPESP 2013/00286-1), and VF (CAPES). LS and AJ thank FAPESP for grants 2013/19486-0 and 2013/08617-7 and CNPq for Productivity Fellowships 304103/2013-6 and 301248/20109. LS thanks Emanuele Kuhn for helping with the manuscript revision. 


\section{References}

Abdel-Monem, N. M., Abdel-Azeem, A. M., El-Ashry, E.-S. H., Ghareeb, D. A., and Nabil-Adam, A. (2013). Pretreatment hepatoprotective effect of the marine fungus derived from sponge on hepatic toxicity induced by heavy metals in rats. Biomed. Res. Int. 2013, 510879. doi: 10.1155/2013/510879

Abe, F., Minegishi, H., Miura, T., Nagahama, T., Usami, R., and Horikoshi, K. (2006). Characterization of cold- and high-pressure-active polygalacturonases from a deep-sea yeast, Cryptococcus liquefaciens strain N6. Biosci. Biotech. Biochem. 70, 296-299. doi: 10.1271/bbb.70.296

Arfi, Y., Chevret, D., Henrissat, B., Berrin, J. G., Levasseur, A., and Record, E. (2013). Characterization of salt-adapted secreted lignocellulolytic enzymes from the mangrove fungus Pestalotiopsis sp. Nat. Commun. 4, 1810. doi: $10.1038 /$ ncomms 2850

Arun, A., Raja, P. P., Arthi, R., Ananthi, M., Kumar, K. S., and Eyini, M. (2008). Polycyclic aromatic hydrocarbons (PAHs) biodegradation by basidiomycetes fungi, Pseudomonas isolate, and their cocultures: comparative in vivo and in silico approach. Appl. Biochem. Biotechnol. 151, 132-142. doi: 10.1007/s12010008-8160-0

Atalla, M. M., Zeinab, H. K., Eman, R. H., Amani, A. Y., and Abeer, A. A. E. A. (2013). Characterization and kinetic properties of the purified Trematosphaeria mangrovei laccase enzyme. Saudi J. Biol. Sci. 20, 373-381. doi: 10.1016/j.sjbs.2013.04.001

Azad, K., Hossain, F., and Halim, M. A. (2013). Screening of cellulase, pectinase and xylanase activities and optimization of radial mycelial growth of two thermophilic fungi. Bangladesh J. Botany. 42, 207-213.

Baker, P. W., Kennedy, J., Dobson, A. D. W., and Marchesi, J. R. (2009). Phylegenetic diversity and antimicrobial activities of fungi associated with Haliclona simulans isolated from Irish coastal waters. Mar. Biotechnol. 11, 540-547. doi: 10.1007/s10126-008-9169-7

Baker, P. W., Kennedy, J., Morrissey, J., O'gara, F., Dobson, A. D. W., and Marchesi, J. R. (2010). Endoglucanase activities and growth of marine-derived fungi isolated from the sponge Haliclona simulans. J. Appl. Microbiol. 108, 1668-1675. doi: 10.1111/j.1365-2672.2009.04563.x

Balabanova, L. A., Gafurov, Y. M., Pivkin, M. V., Terentyeva, N. A., Likhatskaya, G. N., and Rasskazov, V. A. (2012). An extracellular S1-type nuclease of marine fungus Penicillium melinii. Mar. Biotechnol. 14, 87-95. doi: 10.1007/s10126011-9392-5

Baldrian, P., and Gabriel, J. (2003). Lignocellulose degradation by Pleurotus ostreatus in the presence of cadmium. FEMS Microbiol. Lett. 220, 235-240. doi: 10.1016/s0378-1097(03)00102-2

Bamforth, S. M., and Singleton, I. (2005). Bioremediation of polycyclic aromatic hydrocarbons: current knowledge and future directions. J. Chem. Technol. Biotechnol. 80, 723-736. doi: 10.1002/jctb.1276

Basheer, S. M., Chellappan, S., Beena, P. S., Sukumaran, R. K., Elyas, K. K., and Chandrasekaran, M. (2011). Lipase from marine Aspergillus awamori BTMFW032: production, partial purification and application in oil effluent treatment. N. Biotechn. 28, 627-638. doi: 10.1016/j.nbt.2011.04.007

Baughman, G. L., and Weber, E. J. (1994). Transformation of dyes and relatedcompounds in anoxic sediment - kinetics and products. Environ. Sci. Technol. 28, 267-276. doi: 10.1021/es00051a013

Bharathi, S., Saravanan, D., Radhakrishnan, M., and Balagurunathan, R. (2011). Bioprospecting of marine yeast with special reference to inulinase production. Int. J. ChemTech. Res. 3, 1514-1519.

Bliem, R., and Katinger, H. (1988). Scale-up engineering in animal-cell technology.1. Trends Biotechn. 6, 190-195. doi: 10.1016/0167-7799(88)90045-5

Bonugli-Santos, R. C., Durrant, L. R., Da Silva, M., and Sette, L. D. (2010a). Production of laccase, manganese peroxidase and lignin peroxidase by Brazilian marine-derived fungi. Enzyme Microb. Technol. 46, 32-37. doi: 10.1016/j.enzmictec.2009.07.014

Bonugli-Santos, R. C., Durrant, L. R., and Sette, L. D. (2010b). Laccase activity and putative laccase genes in marine-derived basidiomycetes. Fungal Biol. 114, 863-872. doi: 10.1016/j.funbio.2010.08.003

Bonugli-Santos, R. C., Durrant, L. R., and Sette, L. D. (2012). The production of ligninolytic enzymes by marine-derived basidiomycetes and their biotechnological potential in the biodegradation of recalcitrant pollutants and the treatment of textile effluents. Water Air Soil Pollution 223, 2333-2345. doi: $10.1007 /$ s11270-011-1027-y
Booth, T., and Kenkel, N. (1986). "Ecological studies of lignicolous marine fungi: a distribution model based on ordination and classification," in The Biology of Marine Fungi, ed. S. T. Moss (Cambridge: Cambridge University Press), 297-310.

Brauers, G., Edrada, R. A., Ebel, R., Proksch, P., Wray, V., Berg, A., et al. (2000). Anthraquinones and betaenone derivatives from the sponge-associated fungus Microsphaeropsis species: novel inhibitors of protein kinases. J. Nat. Prod. 63, 739-745. doi: 10.1021/np9905259

Bugni, T. S., and Ireland, C. M. (2004). Marine-derived fungi: a chemically and biologically diverse group of microorganisms. Nat. Prod. Rep. 21, 143-163. doi: 10.1039/b301926h

Burtseva, Y. V., Sova, V. V., Pivkin, M. V., Anastyuk, S. D., Gorbach, V. I., and Zvyagintseva, T. N. (2010). Distribution of O-glycosylhydrolases in marine fungi of the sea of Japan and the sea of Okhotsk: characterization of exocellular N-acetyl-beta-D-glucosaminidase of the marine gungus Penicillium canescens. Appl. Biochem. Microbiol. 46, 648-656. doi: 10.1134/s00036838100 60141

Burtseva, Y. V., Verigina, N. S., Sova, V. V., Pivkin, M. V., and Zvyagintseva, T. N. (2003a). Filamentous marine fungi as producers of O-glycosylhydrolases: beta1,3-glucanase from Chaetomium indicum. Mar. Biotechnol. 5, 349-359. doi: 10.1007/s10126-002-0070-2

Burtseva, Y. V., Verigina, N. S., Sova, V. V., Pivkin, M. V., and Zvyagintseva, T. N. (2003b). O-glycosylhydrolases of marine filamentous fungi: beta-1,3 glucanases of Trichoderma aureviride. Prikl. Biokhim. Mikrobiol. 39, 475-481. doi: 10.1023/a:1025444602229

CBD. (2011). Nagoya Protocol on Access to Genetic Resources and the Fair and Equitable Sharing of Benefits Arising from their Utilization to the Convention on Biological Diversity. Quebec: Secretariat of the Convention on Biological Diversity.

Cerniglia, C. E. (1997). Fungal metabolism of polycyclic aromatic hydrocarbons: past, present and future applications in bioremediation. J. Ind. Microbiol. Biotechnol. 19, 324-333. doi: 10.1038/sj.jim.2900459

Cerniglia, C. E., and Sutherland, J. B. (2001). "Bioremediation of polycyclic aromatic hydrocarbons by ligninolytic and non-ligninolytic fungi," in Fungi in Bioremediation. ed. G. M. Gadd (Cambridge: Cambridge University Press).

Chen, H., Wang, M., Shen, Y., and Yao, S. (2014). Optimization of two-species whole-cell immobilization system constructed with marine-derived fungi and its biological degradation ability. Chin. J. Chem. Eng. 22, 187-192. doi: 10.1016/s1004-9541(14)60024-0

Chen, H.-Y., Xue, D.-S., Feng, X.-Y., and Yao, S.-J. (2011). Screening and production of ligninolytic enzyme by a marine-derived fungal Pestalotiopsis sp J63. Appl. Biochem. Biotechnol. 165, 1754-1769. doi: 10.1007/s12010-0119392-y

Chi, Z., Chi, Z., Zhang, T., Liu, G., Li, J., and Wang, X. (2009). Production, characterization and gene cloning of the extracellular enzymes from the marinederived yeasts and their potential applications. Biotechnol. Adv. 27, 236-255. doi: 10.1016/j.biotechadv.2009.01.002

Chi, Z., Ma, C., Wang, P., and Li, H. F. (2007). Optimization of medium and cultivation conditions for alkaline protease production by the marine yeast Aureobasidium pullulans. Bioresour. Technol. 98, 534-538. doi: 10.1016/j.biortech.2006.02.006

Chung, N., Lee, I.-S., Song, H.-S., and Bang, W.-G. (2000). Mechanisms used by white-rot fungi to degrade lignin and toxic chemicals. J. Microbiol. Biotechn. 10, 737-752.

Ciullini, I., Tilli, S., Scozzafava, A., and Briganti, F. (2008). Fungal laccase, cellobiose dehydrogenase, and chemical mediators: combined actions for the decolorization of different classes of textile dyes. Bioresour. Technol. 99, 7003-7010. doi: 10.1016/j.biortech.2008.01.019

Damare, S., Raghukumar, C., Muraleedharan, U. D., and Raghukumar, S. (2006). Deep-sea fungi as a source of alkaline and cold-tolerant proteases. Enzyme Microb. Technol. 39, 172-181. doi: 10.1016/j.enzmictec.2006. 03.032

Da Silva, M., Esposito, E., Joanna, D. M. C., Canhos, V. P., and Cerniglia, C. E. (2004). Metabolism of aromatic hydrocarbons by the filamentous fungus Cyclothyrium sp. Chemosphere 57, 943-952. doi: 10.1016/j.chemosphere.2004.07.051

Da Silva, M., Passarini, M. R. Z., Bonugli, R. C., and Sette, L. D. (2008). Cnidarian-derived filamentous fungi from Brazil: isolation, characterisation 
and RBBR decolourisation screening. Environ. Technol. 29, 1331-1339. doi: 10.1080/09593330802379466

Debashish, G., Malay, S., Barindra, S., and Joydeep, M. (2005). Marine enzymes. Adv. Biochem. Eng. Biotechnol. 96, 189-218. doi: 10.1007/b135785

Del-Cid, A., Ubilla, P., Ravanal, M. C., Medina, E., Vaca, I., Levicán, G., et al. (2014). Cold-active xylanase produced by fungi associated with Antarctic marine sponges. Appl. Biochem. Biotechnol. 172, 524-532. doi: 10.1007/s12010-0130551-1

Dewapriya, P., and Kim, S.-K. (2014). Marine microorganisms: an emerging avenue in modern nutraceuticals and functional foods. Food Res. Int. 56, 115-125. doi: 10.1016/j.foodres.2013.12.022

Dhale, M. A., and Mohan-Kumari, H. P. (2014). A comparative rapid and sensitive method to screen L-asparaginase producing fungi. J. Microbiol. Methods 102, 66-68. doi: 10.1016/j.mimet.2014.04.010

Dhevagi, P., and Poorani, E. (2006). Isolation and characterization of Lasparaginase from marine actinomycetes. Indian J. Biotechn. 5, 514-520.

Diwaniyan, S., Kharb, D., Raghukumar, C., and Kuhad, R. C. (2010). Decolorization of synthetic dyes and textile effluents by basidiomycetous fungi. Water Air Soil Pollution.210, 409-419. doi: 10.1007/s11270-009-0263-x

D’Souza, D. T., Tiwari, R., Sah, A. K., and Raghukumar, C. (2006). Enhanced production of laccase by a marine fungus during treatment of colored effluents and synthetic dyes. Enzyme Microb. Technol. 38, 504-511. doi: 10.1016/j.enzmictec.2005.07.005

D’Souza-Ticlo, D., Sharma, D., and Raghukumar, C. (2009). A thermostable metaltolerant laccase with bioremediation potential from a marine-derived fungus. Mar. Biotechnol. 11, 725-737. doi: 10.1007/s10126-009-9187-0

Duarte, A. W. F., Dayo-Owoyemi, I., Nobre, F. S., Pagnocca, F. C., Chaud, L. C. S., Pessoa, A., et al. (2013). Taxonomic assessment and enzymes production by yeasts isolated from marine and terrestrial Antarctic samples. Extremophiles 17, 1023-1035. doi: 10.1007/s00792-013-0584-y

Dubrovskaya, Y. V., Sova, V. V., Slinkina, N. N., Anastyuk, S. D., Pivkin, M. V., and Zvyagintseva, T. N. (2012). Extracellular beta-D-glucosidase of the Penicillium canescens marine fungus. Appl. Biochem. Microbiol. 48, 401-408. doi: 10.1134/s0003683812040059

El-Gendy, M. M. A. (2010). Keratinase production by endophytic Penicillium spp. Morsy1 under solid-state fermentation using rice straw. Appl. Biochem. Biotechnol. 162, 780-794. doi: 10.1007/s12010-009-8802-x

Elyas, K. K., Mathew, A., Sukumaran, R. K., Ali, P. P. M., Sapna, K., Kumar, S. R., et al. (2010). Production optimization and properties of beta glucosidases from a marine fungus Aspergillus-SA 58. N. Biotechn. 27, 347-351. doi: 10.1016/j.nbt.2010.02.007

Fenice, M., Leuba, J., and Federici, F. (1998). Chitinolytic enzyme activity of Penicillium janthinellum P9 in bench-top bioreactor. J. Ferment. Bioeng. 86, 620-623. doi: 10.1016/s0922-338x(99)80020-8

Gomes, D. N. F., Cavalcanti, M. A. Q., Fernandes, M. J. S., Lima, D. M. M., and Passavante, J. Z. O. (2008). Filamentous fungi isolated from sand and water of "Bairro Novo" and "Casa Caiada" beaches, Olinda, Pernambuco, Brazil. Braz. J. Biol. 68, 577-582. doi: 10.1590/s1519-69842008000300016

Gong, F., Zhang, T., Chi, Z., Sheng, J., Li, J., and Wang, X. (2008). Purification and vharacterization of extracellular inulinase from a marine ueast Pichia guilliermondii and inulin hydrolysis by the purified inulinase. Biotechnol. Bioprocess Eng. 13, 533-539. doi: 10.1007/s12257-007-0177-7

Guo, N., Gong, F., Chi, Z., Sheng, J., and Li, J. (2009). Enhanced inulinase production in solid state fermentation by a mutant of the marine yeast Pichia guilliermondii using surface response methodology and inulin hydrolysis. J. Ind. Microbiol. Biotechnol. 36, 499-507. doi: 10.1007/s10295-008-0519-2

Gupta, R., Gupta, N., and Rathi, P. (2004). Bacterial lipases: an overview of production, purification and biochemical properties. Appl. Microbiol. Biotechnol. 64, 763-781. doi: 10.1007/s00253-004-1568-8

Hallmann, J., Berg, G., and Schulz, B. (2006). "Isolation procedures for endophytic microorganisms," in Microbial Root Endophytes, eds B. E. Schulz, C. C. Boyle, and T. Sieber. (Heidelberg: Springer), 299-319. doi: 10.1007/3-540-335 26-9_17

Hao, O. J., Kim, H., and Chiang, P. C. (2000). Decolorization of wastewater. Crit. Rev. Environ. Sci. Technol. 30, 449-505. doi: 10.1080/10643380091184237

Haritash, A. K., and Kaushik, C. P. (2009). Biodegradation aspects of polycyclic aromatic hydrocarbons (PAHs): a review. J. Hazard. Mater. 169, 1-15. doi: 10.1016/j.jhazmat.2009.03.137
Holler, U., Wright, A. D., Matthee, G. F., Konig, G. M., Draeger, D., and Aust, H. J. et al. (2000). Fungi from marine sponges: diversity, biological activity and secondary metabolites. Mycol. Res. 104, 1354-1365. doi: $10.1017 /$ S0953756200003117

Hou, Y. H., Wang, T. H., Long, H., and Zhu, H. Y. (2006). Novel cold-adaptive Penicillium strain FS010 secreting thermo-labile xylanase isolated from Yellow Sea. Acta Biochim. Biophys. Sin. (Shanghai) 38, 142-149. doi: 10.1111/j.17457270.2006.00135.x

Huang, Y. L., Locy, R., and Weete, J. D. (2004). Purification and characterization of an extracellular lipase from Geotrichum marinum. Lipids 39, 251-257. doi: 10.1007/s11745-004-1227-1

Hyde, K. D., and Jones, E. B. G. (1989). Observations on ascospore morphology in marine fungi and their attachment to surfaces. Botanica Marina 32, 205-218. doi: 10.1515/botm.1989.32.3.205

Hyde, K. D., and Pointing, S. B. (2000). Marine Mycology - A Practical Approach. Hong Kong: Fungal Diversity Press. 1-20.

Intriago, P. (2012). Marine microorganisms: perspectives for getting involved in cellulosic ethanol. AMB Express 2, 46. doi: 10.1186/2191-0855-2-46

Jones, E., Sakayaroj, J., Suetrong, S., Somrithipol, S., and Pang, K. (2009). Classification of marine Ascomycota, anamorphic taxa and Basidiomycota. Fungal Divers. 35, 1-187.

Jones, E. B. G. (2000). Marine fungi: some factors influencing biodiversity. Fungal Divers. 4, 53-73.

Jones, E. B. G., and Pang, K.-L. (2012). Marine Fungi: and Fungal-like Organisms (Marine and Freshwater Botany). Berlin: Walter de Gruyter, 528. doi: $10.1515 / 9783110264067$

Jones, M. D. M., Forn, I., Gadelha, C., Egan, M. J., Bass, D., Massana, R., et al. (2011). Discovery of novel intermediate forms redefines the fungal tree of life. Nature 474, 200-203. doi: 10.1038/nature09984

Junghanns, C., Krauss, G., and Schlosser, D. (2008). Potential of aquatic fungi derived from diverse freshwater environments to decolourise synthetic azo and anthraquinone dyes. Bioresour. Technol. 99, 1225-1235. doi: 10.1016/j.biortech.2007.02.015

Kaushik, C. P., and Haritash, A. K. (2006). Polycyclic aromatic hydrocarbons (PAHs) and environmental health. Our Earth 3, 1-7.

Kjer, J., Debbab, A., Aly, A. H., and Proksch, P. (2010). Methods for isolation of marine-derived endophytic fungi and their bioactive secondary products. Nat. Protoc. 5, 479-490. doi: 10.1038/nprot.2009.233

Kohlmeyer, J., and Kohlmeyer, E. (1979). Marine Mycology: The Higher Fungi. New York, NY: Academic Press.

Kohlmeyer, J., and Volkmann-Kohlmeyer, B. (2003). Fungi from coral reefs: a commentary. Mycol. Res. 107, 386-387. doi: 10.1017/S0953756203227775

Kristensen, J. B., Meyer, R. L., Laursen, B. S., Shipovskov, S., Besenbacher, F., and Poulsen, C. H. (2008). Antifouling enzymes and the biochemistry of marine settlement. Biotechnol. Adv. 26, 471-481. doi: 10.1016/j.biotechadv.2008. 05.005

Levin, L., Herrmann, C., and Papinutti, V. L. (2008). Optimization of lignocellulolytic enzyme production by the white-rot fungus trametes trogii in solid-state fermentation using response surface methodology. Biochem. Eng. J. 39, 207-214. doi: 10.1016/j.bej.2007.09.004

Li, H., Chi, Z., Duan, X., Wang, L., Sheng, J., and Wu, L. (2007a). Glucoamylase production by the marine yeast Aureobasidium pullulans N13d and hydrolysis of potato starch granules by the enzyme. Process Biochem. 42, 462-465. doi: 10.1016/j.procbio.2006.09.012

Li, H., Chi, Z., Wang, X., Duan, X., Ma, L., and Gao, L. (2007b). Purification and characterization of extracellular amylase from the marine yeast Aureobasidium pullulans N13d and its raw potato starch digestion. Enzyme Microb. Techno. 40, 1006-1012. doi: 10.1016/j.enzmictec.2006.07.036

Li, Q., and Wang, G. (2009). Diversity of fungal isolates from three Hawaiian marine sponges. Microbiol. Res. 164, 233-241. doi: 10.1016/j.micres.2007.07.002

Li, X., Chi, Z., Liu, Z., Li, J., Wang, X., and Hirimuthugoda, N. Y. (2008). Purification and characterization of extracellular phytase from a marine yeast Kodamaea ohmeri BG3. Mar. Biotechnol. 10, 190-197. doi: 10.1007/s10126007-9051-z

Ma, C., Ni, X., Chi, Z., Ma, L., and Gao, L. (2007). Purification and characterization of an alkaline protease from the marine yeast Aureobasidium pullulans for bioactive peptide production from different sources. Mar. Biotechnol. 9, 343-351. doi: 10.1007/s10126-006-6105-6 
Madhu, K. M., Beena, P. S., and Chandrasekaran, M. (2009). Extracellular betaglucosidase production by a marine Aspergillus sydowii BTMFS 55 under solid state fermentation using statistical experimental design. Biotechnol. Bioprocess Eng. 14, 457-466. doi: 10.1007/s12257-008-0116-2

Masuma, R., Yamaguchi, Y., Noumi, M., Ōmura, S., and Namikoshi, M. (2001). Effect of sea water concentration on hyphal growth and antimicrobial metabolite production in marine fungi. Mycoscience 42, 455-459. doi: 10.1007/bf02464342

Mayer, A. M. S., Rodriguez, A. D., Taglialatela-Scafati, O., and Fusetani, N. (2013). Marine Pharmacology in 2009-2011: marine compounds with antibacterial, antidiabetic, antifungal, anti-inflammatory, antiprotozoal, antituberculosis, and antiviral activities; affecting the immune and nervous systems, and other miscellaneous mechanisms of action. Mar. Drugs 11, 2510-2573. doi: $10.3390 / \mathrm{md} 11072510$

Mejanelle, L., Lopez, J. F., Gunde-Cimerman, N., and Grimalt, J. O. (2000). Sterols of melanized fungi from hypersaline environments. Org. Geochem. 31, 1031-1040. doi: 10.1016/s0146-6380(00)00094-2

Menezes, C. B. A., Bonugli-Santos, R. C., Miqueletto, P. B., Passarini, M. R. Z., Silva, C. H. D., Justo, M. R., et al. (2010). Microbial diversity associated with algae, ascidians and sponges from the north coast of Sao Paulo state, Brazil. Microbiol. Res. 165, 466-482. doi: 10.1016/j.micres.2009.09.005

Mohan, Y. S. Y. V. J., Sirisha, B., Haritha, R., and Ramana, T. (2013). Selective screening, isolation and characterization of antimicrobial agents from marine actinomycetes. Int. J. Pharm. Pharm. Sci. 5, 443-449.

Mohapatra, B. R., Banerjee, U. C., and Bapuji, M. (1998). Characterization of a fungal amylase from Mucor sp. associated with the marine sponge Spirastrella sp. J. Biotechn. 60, 113-117. doi: 10.1016/s0168-1656(97)00197-1

Morrison-Gardiner, S. (2002). Dominant fungi from Australian coral reefs. Fungal Divers. 9, 105-121.

Mtui, G., and Nakamura, Y. (2008). Lignocellulosic enzymes from flavodon flavus, a fungus isolated from Western Indian Ocean off the coast of Dar es Salaam, Tanzania. Afr. J. Biotechnol. 7, 3066-3072.

Murray, P. M., Moane, S., Collins, C., Beletskaya, T., Thomas, O. P., Duarte, A. W. F., et al. (2013). Sustainable production of biologically active molecules of marine based origin. N. Biotechnol. 30, 839-850. doi: 10.1016/j.nbt.2013.03.006

Nakagiri, A. (2012). "Culture collections and maintenance of marine fungi," in Marine Fungi and Fungal-Like Organisms, eds E. B. G. Jones and K. Pang (Boston: De Gruyter), 501-508.

OECD. (2007). Organization for Economic Co-operation and Development - Best Practice Guidelines for Biological Resource Centres. Paris: OECD.

Orozco, M. R., Hernandez-Saavedra, N. Y., Valle, F. A., Gonzalez, B. A., and Ochoa, J. L. (1998). Cell yield and superoxide dismutase activity of the marine yeast Debaryomyces hansenii under different culture conditions. J. Mar. Biotechnol. 6, 255-259.

Osterhage, C. (2001). Isolation, Structure Determination and Biologicalactivity Assessment of Secondary Metabolites Frommarine-Derived Fungi. Braunschweig: Technischen Universität Carolo-Wilhelmina.

Pang, K., Chow, R. K. K., Chan, C., and Vrijmoed, L. L. P. (2011). Diversity and physiology of marine lignicolous fungi in arctic waters: a preliminary account. Polar Res. 30, 1-5. doi: 10.3402/polar.v30i0.5859

Passarini, M. R. Z., Rodrigues, M. V. N., Da Silva, M., and Sette, L. D. (2011). Marine-derived filamentous fungi and their potential application for polycyclic aromatic hydrocarbon bioremediation. Mar. Pollut. Bull. 62, 364-370. doi: 10.1016/j.marpolbul.2010.10.003

Passarini, M. R. Z., Santos, C., Lima, N., Berlinck, R. G. S., and Sette, L. D. (2013). Filamentous fungi from the Atlantic marine sponge Dragmacidon reticulatum. Arch. Microbiol. 195, 99-111. doi: 10.1007/s00203-012-0854-6

Patil, M. P., Patil, R. H., and Maheshwari, V. L. (2012). A novel and sensitive agar plug assay for screening of asparaginase-producing endophytic fungi from aegle marmelos. Acta Biol. Szeged. 52, 175-177.

Peakall, D. B., Hallett, D. J., Bend, J. R., Foureman, G. L., and Miller, D. S. (1982). Toxicity of prudhoe bay crude-oil and its aromatic fractions to nestling herring-gulls. Environ. Res. 27, 206-215. doi: 10.1016/0013-9351(82)90071-8

Peixoto, R., Rosado, A., and Rg, T. (2008). "Bioprospecção da diversidade microbiana cultivável e não cultivável," in Microbiologia Ambiental, eds I. Melo and J. Azevedo (Jaguariúna: CNPMA/EMBRAPA Editora), 83-106.

Peng, Y., Chi, Z.-M., Wang, X.-H., and Li, J. (2009). Purification and molecular characterization of exo-beta-1,3-glucanases from the marine yeast Williopsis saturnus WC91-2. Appl. Microbiol. Biotechnol. 85, 85-94. doi: 10.1007/s00253009-2061-1.

Prasannarai, K., and Sridhar, K. R. (2001). Diversity and abundance of higher marine fungi on woody substrates along the west coast of India. Curr. Sci. 81, 304-311.

Raghukumar, C., Chandramohan, D., Michel, F. C., and Reddy, C. A. (1996). Degradation of lignin and decolorization of paper mill bleach plant effluent (BPE) by marine fungi. Biotechnol. Lett. 18, 105-106. doi: 10.1007/bf00 137820

Raghukumar, C., D'souza-Ticlo, D., and Verma, A. K. (2008). Treatment of colored effluents with lignin-degrading enzymes: an emerging role of marine-derived fungi. Crit. Rev. Microbiol. 34, 189-206. doi: 10.1080/10408410802526044

Raghukumar, C., Muraleedharan, U., Gaud, V. R., and Mishra, R. (2004a). Simultaneous detoxification and decolorization of molasses spent wash by the immobilized white-rot fungus flavodon flavus isolated from a marine habitat. Enzyme Microb. Technol. 35, 197-202. doi: 10.1016/j.enzmictec.2004.04.010

Raghukumar, C., Muraleedharan, U., Gaud, V. R., and Mishra, R. (2004b). Xylanases of marine fungi of potential use for biobleaching of paper pulp. J. Ind. Microbiol. Biotechnol. 31, 433-441. doi: 10.1007/s10295-004-0165-2

Raghukumar, C., Raghukumar, S., Chinnaraj, A., Chandramohan, D., Dsouza, T. M., and Reddy, C. A. (1994). Laccase and other lignocellulose modifying enzymes of marine fungi isolated from the coast of India. Botanica Marina 37, 515-523. doi: 10.1515/botm.1994.37.6.515

Raghukumar, C., Shailaja, M. S., Parameswaran, P. S., and Singh, S. K. (2006). Removal of polycyclic aromatic hydrocarbons from aqueous media by the marine fungus NIOCC\#312: involvement of lignin-degrading enzymes and exopolysaccharides. Indian J. Mar. Sci. 35, 373-379.

Rämä, T., Norden, J., Davey, M. L., Mathiassen, G. H., Spatafora, J. W., and Kauserud, H. (2014). Fungi ahoy! Diversity on marine wooden substrata in the high North. Fungal Ecol. 8, 46-58. doi: 10.1016/j.funeco.2013.12.002

Reetz, M. T. (2006). Directed evolution of enantioselective enzymes as catalysts for organic synthesis. Adv. Catal. 49, 1-69. doi: 10.1016/s0360-0564(05)49001-x

Richards, T. A., Jones, M. D. M., Leonard, G., and Bass, D. (2012). Marine fungi: their ecology and molecular diversity. Ann. Rev. Mar. Sci. 4, 495-522. doi: 10.1146/annurev-marine-120710-100802

Sarkar, S., Pramanik, A., Mitra, A., and Mukherjee, J. (2010). Bioprocessing data for the production of marine enzymes. Mar. Drugs 8, 1323-1372. doi: $10.3390 / \mathrm{md} 8041323$

Schulz, B., Draeger, S., Dela Cruz, T. E., Rheinheimer, J., Siems, K., Loesgen, S., et al. (2008). Screening strategies for obtaining novel, biologically active, fungal secondary metabolites from marine habitats. Botanica Marina 51, 219-234. doi: 10.1515/bot.2008.029

Sette, L. D., and Bonugli-Santos, R. C. (2013). "Ligninolytic enzymes from marinederived fungi: production and applications," in Marine Enzymes for Biocatalysis: Sources Biocatalytic Characteristics and Bioprocesses of Marine Enzymes, ed. A. Trincone (Cambridge: Woodhead Publishing Limited), 403-427.

Sette, L. D., Cupolillo, E., Tigano, M. S., Vazoller, R. F., and Canhos, V. P. (2007). Recomendações para operação e gerenciamento de coleções de culturas de microrganismos. Microbiol. Foco. (Brazilian Society of Microbiology) 2, 49-55.

Sette, L. D., Pagnocca, F. C., and Rodrigues, A. (2013). Microbial culture collections as pillars for promoting fungal diversity, conservation and exploitation. Fungal Genet. Biol. 60, 2-8. doi: 10.1016/j.fgb.2013.07.004

Sheng, J., Chi, Z., Gong, F., and Li, J. (2008). Purification and characterization of extracellular inulinase from a marine yeast Cryptococcus aureus G7a and inulin hydrolysis by the purified inulinase. Appl. Biochem. Biotechnol. 144, 111-121. doi: 10.1007/s12010-007-8025-y

Shuttleworth, K. L., and Cerniglia, C. E. (1995). Environmental aspects of PAH biodegradation. Appl. Biochem. Biotechnol. 54, 291-302. doi: 10.1007/BF02787927

Singh, A. K., and Mukhopadhyay, M. (2012). Overview of fungal lipase: a review. Appl. Biochem. Biotechnol. 166, 486-520. doi: 10.1007/s12010-011-9444-3

Singh, A. K., Prakash, D., and Shahi, S. K. (2013). Decolorization of the textile dye (Brown GR) by isolated Aspergillus strain from Meerut region. Int. Res. J. Environ. Sci. 2, 25-29.

Singh, B. K. (2010). Exploring microbial diversity for biotechnology: the way forward. Trends Biotechnol. 28, 111-116. doi: 10.1016/j.tibtech.2009.11.006

Singh, R. P., Gupta, V., Kumari, P., Kumar, M., Reddy, C. R. K., Prasad, K., et al. (2011). Purification and partial characterization of an extracellular alginate 
lyase from Aspergillus oryzae isolated from brown seaweed. J. Appl. Phycol. 23, 755-762. doi: 10.1007/s10811-010-9576-9

Sode, K., Ishimura, F., and Tsugawa, W. (2001). Screening and characterization of fructosyl-valine-utilizing marine microorganisms. Mar. Biotechnol. 3, 126-132. doi: $10.1007 / \mathrm{s} 101260000065$

Song, C., Liu, G.-L., Xu, J.-L., and Chi, Z.-M. (2010). Purification and characterization of extracellular beta-galactosidase from the psychrotolerant yeast guehomyces pullulans 17-1 isolated from sea sediment in Antarctica. Process Biochem. 45, 954-960. doi: 10.1016/j.procbio.2010.02.025

Sowell, S. M., Norbeck, A. D., Lipton, M. S., Nicora, C. D., Callister, S. J., Smith, R. D., et al. (2008). Proteomic analysis of stationary phase in the marine bacterium "Candidatus Pelagibacter ubique." Appl. Environ. Microbiol. 74, 4091-4100. doi: 10.1128/aem.00599-08

Sponga, F., Cavaletti, L., Lazzarini, A., Borghi, A., Ciciliato, I., Losi, D., et al. (1999). Biodiversity and potentials of marine-derived microorganisms. J. Biotechnol. 70, 65-69. doi: 10.1016/s0168-1656(99)00059-0

Teixeira, V. L., Paixão, I. C. N. D. P., Villaça, R. C., and Cavalcanti, D. N. (2010). Caracterização Do Estado Da Arte Em Biotecnologia Marinha No Brasil. Brasília: Série B.

Thenmozhi, C., Sankar, R., Karuppiah, V., and Sampathkumar, P. (2011). Lasparaginase production by mangrove derived Bacillus cereus MAB5: optimization by response surface methodology. Asian Pac. J. Trop. Biomed. 4, 486-491. doi: 10.1016/s1995-7645(11)60132-6

Trincone, A. (2010). Potential biocatalysts originating from sea environments. J. Mol. Catal. B Enzym. 66, 241-256. doi: 10.1016/j.molcatb.2010.06.004

Trincone, A. (2011). Marine biocatalysts: enzymatic features and applications. Mar. Drugs 9, 478-499. doi: 10.3390/md9040478

Velmurugan, N., Kalpana, D., Han, J. H., Cha, H. J., and Lee, Y. S. (2011). A novel low temperature chitinase from the marine fungus Plectosphaerella sp strain MF-1. Botanica Marina 54, 75-81. doi: 10.1515/bot.2010.068

Velmurugan, N., and Lee, Y. S. (2012). "Enzymes from marine fungi: current research and future prospects," in Marine Fungi and Fungal-like Organisms (Marine and Freshwater Botany), ed. E. B. G. Jones (Berlin: Walter de Gruyter), 441-474.

Verbist, J., Sallenave, C., and Pouchus, Y. (2000). Marine fungal substances. Stud. Nat. Prod. Chem. 24, 979-1092. doi: 10.1016/S1572-5995(00)80059-9

Verma, A. K., Raghukumar, C., Verma, P., Shouche, Y. S., and Naik, C. G. (2010). Four marine-derived fungi for bioremediation of raw textile mill effluents. Biodegradation 21, 217-233. doi: 10.1007/s10532-009-9295-6

Vijaykrishna, D., Jeewon, R., and Hyde, K. D. (2006). Molecular taxonomy, origins and evolution of freshwater ascomycetes. Fungal Divers. 23, 351-390.

Voget, S., Leggewie, C., Uesbeck, A., Raasch, C., Jaeger, K. E., and Streit, W. R. (2003). Prospecting for novel biocatalysts in a soil metagenome. Appl. Environ. Microbiol. 69, 6235-6242. doi: 10.1128/aem.69.10.6235-6242.2003
Vrijmoed, L. L. P. (2000). "Isolation and culture of higher filamentous fungi," in Marine Mycology - A Practical Approach, eds K. D. Hyde and S. B. Pointing (Hong Kong: Fungal Diversity Press), 1-20.

Wang, Q., Hou, Y., Shi, Y., Han, X., Chen, Q., Hu, Z., et al. (2012). Cloning, expression, purification, and characterization of glutaredoxin from Antarctic Sea-Ice bacterium Pseudoalteromonas sp. AN178. BioMed. Res. Int. 2014. 246871. doi: $10.1155 / 2014 / 246871$

WFCC (2010). World Federation for Culture Collections - Guidelines for the Establishment and Operation of Collections of Cultures of Micro-Organisms, 3rd Edn. Brussel: WFCC.

Wu, Q., Zhang, M., Wu, K., Liu, B., Cai, J., and Pan, R. (2011). Purification and characteristics of fucoidanase obtained from Dendryphiella arenaria TM94. J. Appl. Phycol. 23, 197-203. doi: 10.1007/s10811-010-9588-5

Wu, Y.-R., He, T.-T., Lun, J.-S., Maskaoui, K., Huang, T.-W., and Hu, Z. (2009). Removal of benzo a pyrene by a fungus Aspergillus sp BAP14. World J. Microbiol. Biotechnol. 25, 1395-1401. doi: 10.1007/s11274-0090026-2

Zaharia, C., and Suteu, D. (2012). "Textile organic dyes - characteristics, polluting effects and separation/elimination procedures from industrial effluents - a critical overview," in Organic Pollutants Ten Years After the Stockholm ConventionEnvironmental and Analytical Update, eds T. Puzyn and A. Mostrag-Szlichtyng (Rijeka: Intech).

Zhang, C., and Kim, S. K. (2010). Research and application of marine microbial enzymes: status and prospects. Marine Drugs 8, 1920-1934. doi: $10.3390 / \mathrm{md} 8061920$

Zhang, C., and Kim, S. K. (2012). Application of marine microbial enzymes in the food and pharmaceutical industries. Adv. Food Nutr. Res. 65, 423-435. doi: 10.1016/B978-0-12-416003-3.00028-7

Zhuravleva, N. V., Luk'yanov, P. A., and Pivkin, M. V. (2004). N-acetyl-betaD-hexosaminidase secreted by the marine fungus Phoma glomerata. Appl. Biochem. Microbiol. 40, 448-453. doi: 10.1023/b:abim.0000040666.13870.52

Conflict of Interest Statement: The authors declare that the research was conducted in the absence of any commercial or financial relationships that could be construed as a potential conflict of interest.

Copyright (c) 2015 Bonugli-Santos, dos Santos Vasconcelos, Passarini, Vieira, Lopes, Mainardi, dos Santos, de Azevedo Duarte, Otero, da Silva Yoshida, Feitosa, Pessoa and Sette. This is an open-access article distributed under the terms of the Creative Commons Attribution License (CC BY). The use, distribution or reproduction in other forums is permitted, provided the original author(s) or licensor are credited and that the original publication in this journal is cited, in accordance with accepted academic practice. No use, distribution or reproduction is permitted which does not comply with these terms. 